\title{
Corticosteroid Regulation of lon Channel Conductances and mRNA Levels in Individual Hippocampal CA1 Neurons
}

\author{
Suresh M. Nair, ${ }^{1}$ Taco R. Werkman, ${ }^{3}$ Johanna Craig, ${ }^{4}$ Richard Finnell,, ${ }^{4}$ Marian Joëls, ${ }^{3}$ and \\ James H. Eberwine ${ }^{1,2}$ \\ Departments of ${ }^{1}$ Pharmacology and ${ }^{2}$ Psychiatry, University of Pennsylvania Medical Center, Philadelphia, Pennsylvania \\ 19104, ${ }^{3}$ Department of Experimental Zoology, University of Amsterdam, 1098 SM Amsterdam, The Netherlands, and \\ ${ }^{4}$ Department of Veterinary Anatomy and Public Health, College of Veterinary Medicine, Texas Agriculture and Mining \\ University, College Station, Texas 77843-4458
}

Overexposure to corticosteroid hormones is harmful to hippocampal neuronal integrity, likely by perturbation of calcium homeostasis. To identify molecular mechanisms at the singlecell level, we characterized mRNA expression corresponding to voltage- and ligand-gated $\mathrm{Ca}$ channels in individual dissociated CA1 neurons in response to long-term corticosterone (CORT) exposure. Predominant mineralocorticoid receptor occupation (ADC-LO group) resulted in low levels of P/Q- and L-type Ca channel mRNAs, high levels of GluR-2 versus GluR-1, and a high ratio of NMDAR-2A to NMDAR-2B mRNA. Corresponding alterations in protein expression were consistent with the restriction of $\mathrm{Ca}$ influx. In contrast, additional glucocorticoid receptor occupation (ADC-HI group) altered the expression of these mRNAs in a manner consistent with enhanced $\mathrm{Ca}$ influx; interestingly, qualitatively similar alterations were seen in control ADX neurons. Electrophysiological data from the same neurons indicate that $\mathrm{Ca}$ current amplitudes also are modulated by CORT, although on a shorter time scale. Finally, principal components analysis (PCA) suggests that neuronal AMPA and NMDA receptor composition may be regulated by MR and GR activation in a complex manner. Therefore, our data implicate molecular events by which CORT may regulate $\mathrm{Ca}$ influx into CA1 hippocampal neurons.

Key words: corticosterone; dissociated CA1 Neurons; aRNA amplification; expression profile; mRNA; ion channels; hippocampus
Adrenal corticosteroid hormones such as corticosterone (CORT) mediate a wide range of metabolic, immune-suppressive, and anti-inflammatory responses to stress (Bohus et al., 1982; Funder, $1987)$. CORT binds with high affinity $\left(K_{\mathrm{D}}=0.5 \mathrm{nM}\right)$ to mineralocorticoid receptors (MRs) and with 10 -fold lower affinity $\left(K_{\mathrm{D}}\right.$ $=5 \mathrm{nM}$ ) to glucocorticoid receptors (GRs) in rat hippocampal CA1 neurons (Hollenberg et al., 1985; Reul and de Kloet, 1985; Arriza et al., 1987; Chao et al., 1989; Herman et al., 1989). These ligand-bound receptors interact with sequence-specific genomic response elements and regulate transcriptional activity (Rousseau, 1984; McEwen et al., 1986; Funder, 1987). Therefore, the actions of CORT on MRs and GRs alter the expression of cellular mRNAs and proteins and influence fundamental properties of hippocampal neurons.

Selective occupation of MRs by CORT is associated with small amplitudes of both T- and L-type Ca currents in CA1 neurons from slice preparations (Karst et al., 1994). Additional activation of GRs resulted in increased amplitudes, particularly of L-type currents (Kerr et al., 1992; Karst et al., 1994). Other Cadependent phenomena, e.g., the accommodation in cell firing and slow after hyperpolarization observed with brief depolarization

Received Nov. 18, 1996; revised Dec. 23, 1997; accepted Jan. 14, 1998.

T.R.W. was supported by Grant 900-553-091 from the Netherlands Organization for Scientific Research. S.M.N. and J.H.E. were supported by National Institutes of Health Grant AG9900. This work was also supported in part by NATO Collaborative Research Grant 971033. The assistance of W. Hesen in hippocampal cell preparations is gratefully acknowledged.

S.M.N. and T.R.W. contributed equally to this project.

Correspondence should be addressed to Dr. James H. Eberwine, Department of Pharmacology, University of Pennsylvania Medical Center, 36th and Hamilton Walk, Philadelphia, PA 19104-6084.

Copyright (C) 1998 Society for Neuroscience $\quad 0270-6474 / 98 / 182685-12 \$ 05.00 / 0$ of CA1 neurons, also displayed a comparable dependency on the extent of MR and GR occupation (Joëls and de Kloet, 1989, 1994; Kerr et al., 1989). Corticosteroid receptor-mediated effects on Ca conductances and other neuronal properties were slow in onset and required protein synthesis (Karst and Joëls, 1991; Kerr et al., 1992), suggesting a genomic component of action.

Many reports in the literature suggest that MR activation can be neuroprotective in the hippocampus (Landfield et al., 1981; Gould et al., 1990; Joëls and de Kloet, 1996). Chronically, absence of circulating CORT in ADX rats, as well as exposure to high doses of CORT, increases neuronal vulnerability, sometimes resulting in cell death (Sapolsky et al., 1985; Sloviter et al., 1989; Gould et al., 1990; Woolley et al., 1990), particularly when concomitant excitatory challenges are present (Sapolsky and Pulsinelli, 1985; Sapolsky et al., 1988). Chronically elevated Ca influx associated with a high dose of CORT is thought to endanger hippocampal neurons (Elliot and Sapolsky, 1993; Elliot et al., 1993) via NMDA receptor-dependent processes (Choi, 1988; Armanini et al., 1990; Tymianski et al., 1994).

In the present study we examined whether prolonged changes in average plasma CORT levels affect mRNA expression for proteins contributing to $\mathrm{Ca}$ influx and $\mathrm{Ca}$-mediated synaptic transmission in CA1 pyramidal neurons. These included the $\alpha 1$ subunits of neuronal Ca channels, e.g., $\alpha 1 \mathrm{~A}, \alpha 1 \mathrm{~B}$, and $\alpha 1 \mathrm{C} / \mathrm{D}$, encoding P-, N- and L-type Ca channels, respectively (Varadi et al., 1995), subunits of the AMPA (GluR-1, R-2, R-3, and R-4) and NMDAR-1, R-2A, R-2B, and R-2C receptors. To this end, we used the technique of single-cell antisense RNA amplification and expression profiling (Eberwine et al., 1992), subsequent to electrophysiological recording of voltage-gated Ca currents from 
isolated CA1 neurons (Kay and Wong, 1986). Thus, regulation of $\mathrm{Ca}$ conductances, as well as expression of mRNAs encoding $\mathrm{Ca}$ channel proteins, was characterized in the same neurons. Four experimental groups were investigated: (1) rats that were adrenalectomized 3-4 weeks before the experiments so that MRs and GRs were chronically unoccupied (ADX); (2) ADX rats that received a low dose of CORT $(20 \mu \mathrm{g} / \mathrm{ml})$ in their drinking water so that mostly MRs, but not GRs, were activated (ADC-LO) (Jacobson et al., 1988); (3) ADX rats that received a very high CORT dose $(300 \mu \mathrm{g} / \mathrm{ml})$, resulting in activation of GRs in addition to MRs (ADC-HI); and (4) sham-operated controls (SHAM). These treatments were performed for 4 weeks.

\section{MATERIALS AND METHODS}

Treatment paradigm. Groups of adult male Sprague Dawley rats (average weight, 100-200 gm) were adrenalectomized bilaterally or shamoperated and treated for 4 weeks with $0.9 \%$ saline and $1.5 \%$ ethanol in their drinking water. The following additions were made to their water 1-2 d after the operation: ADX, none; SHAM, none; ADC-LO, CORT $(20 \mu \mathrm{g} / \mathrm{ml})$; ADC-HI, CORT (300 $\mu \mathrm{g} / \mathrm{ml})$. On the day of the experiment, rats were exposed for 30-60 min to a novel environment and then ether-anesthetized and killed. Their brains were dissected quickly and stored at $0^{\circ} \mathrm{C}$ in artificial $\mathrm{CSF}$ of the following composition (in $\mathrm{mm}$ ): $\mathrm{NaCl} 120, \mathrm{KCl} 3.5, \mathrm{MgSO}_{4} 1.3, \mathrm{NaH}_{2} \mathrm{PO}_{4} 1.25, \mathrm{CaCl}_{2}$ 2.5, D-glucose 10 , and $\mathrm{NaHCO}_{3} 25$. Trunk blood taken at this time was used to measure plasma CORT levels by the use of standard radio immunoassay (RIA) procedures. Because of the experimental procedure, sham-operated controls showed a moderate elevation of the plasma corticosterone level $(\sim 10 \mu \mathrm{g} / 100 \mathrm{ml})$.

Acute isolation of CA1 neurons, electrical recording, and first-strand cDNA synthesis. The hippocampus was dissected, and 300-400 $\mathrm{mm}$ slices were made with a McIllwain tissue chopper. The slices were collected in cold $\left(4^{\circ} \mathrm{C}\right)$ oxygenated dissociation medium (composition in mM: PIPES

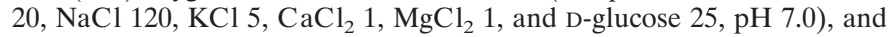
CA1 regions were dissected from the slices to isolate individual neurons according to the method of Kay and Wong (1986). The CA1 cubes were incubated for $\sim 80 \mathrm{~min}$ at $32^{\circ} \mathrm{C}$ in oxygenated dissociation medium with $1 \mathrm{mg} / \mathrm{ml}$ trypsin (type XI, Sigma, St. Louis, MO). Subsequently, the cubes were transferred to trypsin-free oxygenated dissociation medium and kept at $15-20^{\circ} \mathrm{C}$. To yield isolated CA1 neurons, we triturated two CA1 cubes per time in extracellular recording medium (composition in mM: HEPES 10, $\mathrm{NaCl} 110, \mathrm{CaCl}_{2} 5, \mathrm{KCl} 5, \mathrm{MgCl}_{2}$ 1, D-glucose 25, TEA-Cl 25, 4-aminopyridine 25, and TTX 0.5, pH 7.4) with a Pasteur pipette.

After the neurons settled to the bottom of the recording chamber, they were approached with a patch electrode (resistance 2-4 M $\Omega$ ) filled with electrode solution of the following composition (in mM): HEPES 10, CsF $100, \mathrm{MgCl}_{2}$ 4, TEA-Cl 20, EGTA 5, Mg-ATP 2, Na-GTP 0.1, creatine phosphate 20 , and leupeptin 0.1 , with creatine phosphokinase $50 \mathrm{U} / \mathrm{ml}$, pH 7.3; a high-resistance seal was made. To establish the whole-cell voltage-clamp configuration, we ruptured the membrane under the patch electrode by light suction. Ca currents were recorded with an Axopatch 200 amplifier (Axon Instruments, Foster city, CA) and filtered at $5 \mathrm{kHz}$ with the four-pole Bessel filter on the amplifier. Pipette and cell capacitance transients were compensated with the appropriate capacitance controls on the amplifier, and series resistance compensation was applied to a level of $80-90 \%$. Voltage steps were generated, and currents were acquired at $1 \mathrm{kHz}$ with an ADC converter under control of an Atari PC; they were digitized and stored on magnetic media for later analysis. Current-voltage relationships were determined.

After these measurements the cell contents were aspirated into the recording pipette (volume of intracellular recording solution plus cell content was $\sim 10 \mu \mathrm{l}$ ) and transferred to a tube containing $0.5 \mu \mathrm{l}$ of 30 $\mathrm{U} / \mu \mathrm{l}$ RNase inhibitor. Subsequently, reagents were added for first-strand cDNA synthesis. The composition and approximate final concentrations (because of variations in volume of the aspirated cell content) of these reagents were (in $\mathrm{mm}$ ) $130 \mathrm{~K}$-gluconate, $10 \mathrm{KCl}, 6 \mathrm{MgCl}_{2}$, and 10 HEPES with $500 \mu \mathrm{M}$ each dATP, dCTP, dGTP, and TTP, plus $1.5 \mathrm{ng} / \mu \mathrm{l}$ oligo-dT-T7 primer. This mixture was heated to $90^{\circ} \mathrm{C}$ for $9 \mathrm{~min}$ and then cooled to $39^{\circ} \mathrm{C}$, after which the AMV Seikagaku reverse transcriptase was added (final concentration $\sim 1 \mathrm{U} / \mu \mathrm{l}$ ) in the presence of which the mixture was incubated for another $90 \mathrm{~min}\left(\right.$ at $\left.39^{\circ} \mathrm{C}\right)$. Next, the mixture was cooled to $0^{\circ} \mathrm{C}$ and tRNA, $\mathrm{NaCl}$ (final concentrations $25 \mathrm{ng} / \mathrm{ml}$ and $0.2 \mathrm{~mm}$, respectively), and ethanol were added to precipitate first-strand cDNA.

Antisense RNA amplification: first and second round. The singlestranded cDNA population was purified by phenol-chloroform extraction and ethanol precipitation. Then it was made double-stranded by the Gubler-Hoffmann method; the hairpin loop was excised and blunt-ended by standard procedures. The cDNA template was purified by dialysis before incubation with the following reagents at $37^{\circ} \mathrm{C}$ for $3.5 \mathrm{hr}$ to generate ${ }^{32} \mathrm{P}$-labeled antisense RNA (aRNA) (in mM): 40 Tris buffer, $\mathrm{pH}$ $7.5,7 \mathrm{MgCl}_{2}, 10 \mathrm{NaCl}, 2$ spermidine, and 8 DTT plus $250 \mu \mathrm{M} \mathrm{ATP,} \mathrm{GTP,}$ and UTP, $25 \mu \mathrm{M}$ CTP, $30 \mu \mathrm{Ci}$ of [ $\left.{ }^{32} \mathrm{P}\right] \mathrm{CTP}, 20 \mathrm{U}$ of RNase inhibitor, and $1000 \mathrm{U}$ of T7 RNA polymerase. A fraction of the ${ }^{32} \mathrm{P}$-labeled aRNA was electrophoresed on a denaturing formaldehyde gel. Then the gel was washed in $10 \% \mathrm{w} / \mathrm{v}$ trichloroacetic acid (TCA), blotted dry for $12 \mathrm{hr}$, and apposed to $\mathrm{x}$-ray film to assess the size distribution of the first-round aRNA population.

Purified first-round aRNA was incubated at $37^{\circ} \mathrm{C}$ with $100 \mathrm{ng}$ of random primers, $40 \mathrm{U}$ of RNase inhibitor, $40 \mathrm{U}$ of Seikagaku AMV reverse transcriptase, and $250 \mu \mathrm{M}$ dNTPs under appropriate buffer conditions [(in mM) 50 Tris, $\mathrm{pH} 8.0,6 \mathrm{MgCl}_{2}, 120 \mathrm{KCl}$, and $7 \mathrm{DTT}$ ] to generate the corresponding complementary DNA population. The resulting cDNA population was in the sense orientation relative to the original poly $\left(\mathrm{A}^{+}\right)$RNA population and had poly $(\mathrm{dA})$ tails. The oligodT-T7 amplification primer was used to synthesize double-stranded cDNA by using T4 DNA polymerase. This cDNA population was made blunt-ended as before, dialyzed, and amplified to generate a ${ }^{32} \mathrm{P}$-labeled aRNA population antisense in orientation to the original poly $\left(\mathrm{A}^{+}\right)$ population. Under optimal conditions, resulting aRNA was amplified linearly over the latter by greater than a million-fold. This was used to probe slot blots loaded with candidate cDNA clones (below).

Preparation of slot blots and probe addition. Amersham's Hybond-N nylon membrane (Arlington Heights, IL) was wetted with distilled deionized $\mathrm{H}_{2} \mathrm{O}$ and $10 \times \mathrm{SSC}$ before use in the slot blot apparatus. One microgram of each linearized plasmid cDNA in $10 \times$ SSC corresponding to candidate mRNA sequences was heat-denatured $\left(85^{\circ} \mathrm{C}\right.$ for $\left.7 \mathrm{~min}\right)$ and loaded per slot under gravity. The cDNAs were fixed to the nylon membrane by UV-cross-linking.

Slot blots were prehybridized in heat-sealed plastic bags containing $50 \% \mathrm{v} / \mathrm{v}$ formamide, $5 \times$ SSC, $5 \times$ Denhardt's reagent, $0.5 \% \mathrm{w} / \mathrm{v}$ SDS, 100 $\mu \mathrm{g} / \mathrm{ml}$ salmon sperm DNA, and $1 \mathrm{~mm} \mathrm{Na}$ pyrophosphate for $12 \mathrm{hr}$. ${ }^{32}$ P-labeled aRNA probe (not less than $10^{7}$ counts) was heat-denatured and added to the bags. After a hybridization period of $\sim 48 \mathrm{hr}$, blots were washed two times for $15 \mathrm{~min}$ in $2 \times \mathrm{SSC}, 0.1 \% \mathrm{w} / \mathrm{v}$ SDS at $42^{\circ} \mathrm{C}$, followed by two times for $15 \mathrm{~min}$ washes in $0.1 \times \mathrm{SSC}, 1 \% \mathrm{w} / \mathrm{v}$ SDS at $55^{\circ} \mathrm{C}$. The latter wash was repeated until the signal corresponding to $1 \mu \mathrm{g}$ of plasmid vector cDNA on the slot blots that represented nonspecific binding of the aRNA probe was judged to be sufficiently low. The blots were air-dried and apposed to a phosphor screen, which then was analyzed on a phosphorimager with ImageQuant software.

Data analysis. The density of bands corresponding to candidate cDNA clones was measured by analysis on the phosphorimager. The specific signal (above background) of probe bound to each clone was expressed as a percentage of the sum of specific signals for the $\alpha$-subunits of the neuronal $\mathrm{GABA}_{\mathrm{A}}$ receptor-the "inhibitory component" of CA1 neurons. With the exception of $\alpha 1$ mRNA, there were no alterations in other $\alpha$-subunit mRNAs among treatment groups. Because $\alpha 1$ mRNA represented between 2 and $4 \%$ of total $\alpha$-subunit mRNA signal in all neurons examined, this difference is unlikely to have an impact on our analysis.

Use of internal references minimized variations caused by differences in specific activity of the probe and absolute quantity of the probe present. Relative abundances of multiple candidate mRNAs in individual CA1 neurons from each treatment group were characterized. Further, alterations in relative steady-state mRNA levels in CA1 neurons from ADC-LO and ADC-HI treatment groups were quantified relative to the ADX-V and SHAM control groups. Such an analysis of concomitant expression of multiple candidate mRNAs is called expression profiling.

Data from the four groups were tested first with a one-way ANOVA, followed by a post hoc multiple comparison of the means, using a Student's $t$ test.

Principal components and univariate ratio analyses. Uni- and multivariate statistical procedures were performed on mRNA expression data for 10 genes generated from individual SHAM CA1 neurons. Alterations in the relative levels of gene expression may be correlated with changes in 
Table 1. Correlations among treatment groups, average daily CORT intake, measured plasma CORT levels, and Ca conductance properties

\begin{tabular}{|c|c|c|c|c|c|c|c|}
\hline Treatment & Initial weight & Final weight & [CORT] intake & [CORT]-RIA & Capacitance & $\begin{array}{l}\text { Input } \\
\text { impedance }\end{array}$ & $N, \mathrm{n}, n$ \\
\hline SHAM & $159.3 \pm 4.4$ & $305.3 \pm 6.8$ & $0.0 \pm 0.0$ & $11.6 \pm 3.0$ & $8.8 \pm 0.6$ & $502 \pm 46$ & $7,12,14$ \\
\hline ADX & $156.0 \pm 8.5$ & $261.2 \pm 9.2$ & $0.0 \pm 0.0$ & $0.3 \pm 0.1$ & $7.3 \pm 0.5$ & $800 \pm 145$ & $9,11,18$ \\
\hline ADC-LO & $166.0 \pm 12.1$ & $290.0 \pm 14.5$ & $0.76 \pm 0.02$ & $0.5 \pm 0.2$ & $8.6 \pm 0.5$ & $633 \pm 69$ & $7,12,17$ \\
\hline ADC-HI & $146.5 \pm 3.9$ & $154.5 \pm 12.3$ & $10.28 \pm 0.78$ & $4.1 \pm 1.0$ & $8.5 \pm 0.7$ & $827 \pm 124$ & $6,9,16$ \\
\hline
\end{tabular}

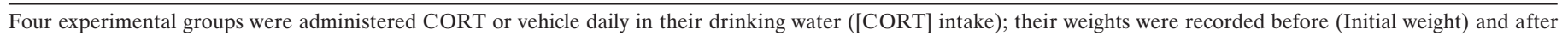

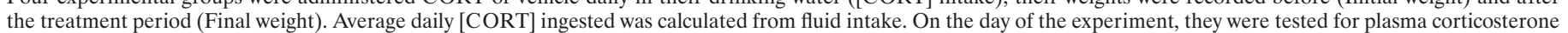

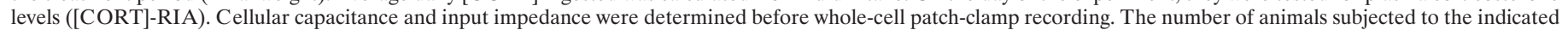

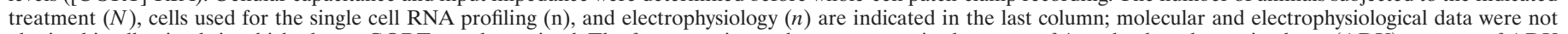

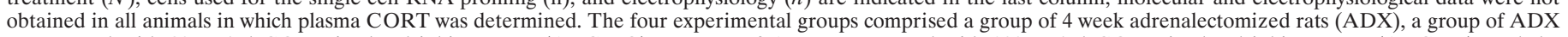

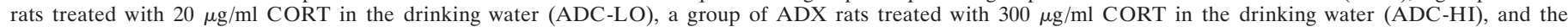
sham-operated controls (SHAM).

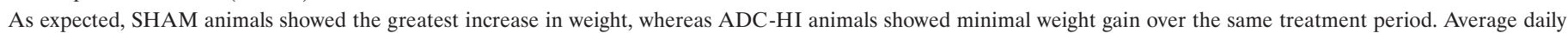

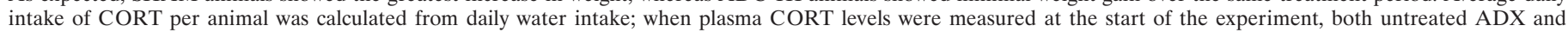

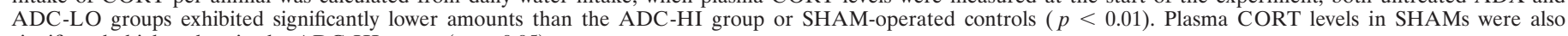
significantly higher than in the ADC-HI group $(p<0.05)$.

cellular physiology induced by exposure to various treatment conditions (e.g., ADX, ADC-LO, and ADC-HI). These changes potentially can be used to determine characteristic patterns of mRNA expression and, in a sense, to define "diagnostic" molecular fingerprints for each of these treatment states relative to the control condition.

Principal components analysis (PCA) is an exploratory technique that attempts to describe interrelationships among a number of given variables, e.g., characterization of complex interactions between morphoregulatory genes during normal embryonic development (Craig et al., 1997) or as a consequence of drug-induced teratogenesis (Bennett et al., 1997). In the present investigation PCA was used to examine the interrelationships between candidate genes in normal SHAM CA1 neurons. It should be noted that the categorical data used in these procedures represented measurements obtained from the densitometry analysis. These measurements were log-transformed to normalize the data for use in the PCA. First, log-transformed mRNA expression data were consolidated into eigenvector (coefficient)-based variables known as principal components or PCs. PCs have the following properties: first, they are uncorrelated and independent; second, each PC describes a percentage of the variability associated with the original data (Rao, 1973; Rohif and Bookstein, 1990; Johnson and Wichern, 1992). The use of PCs enables simultaneous analysis of expression of multiple mRNAs and assessment of patterning differences and/or similarities among a group of observations. This technique starts with a measure of the interdependence of the original data, the covariance matrix, and creates a set of new variables (PCs) with a sample covariance matrix that indicates their independence from each other. This is accomplished by finding linear or additive combinations of the original variables, the coefficients of which are equal to the eigenvectors of the covariance matrix. Thus all of the original mRNA expression data are consolidated to single PCs, which can be viewed and interpreted independently and can replace the initial expression variables. Because the log transformation yields ratio measurements (as mentioned above), the gene data represented as PC coefficients could be discussed in terms of ratio relationships. The eigenvectors, or PC coefficients, relate the PCs back to the original mRNA expression variables and are scaled so that their sum of squares is unity. This enables us to determine which of the expression variables dominate a PC, as well as to interpret its structure. For convenience, the PCs are sorted in descending order of the percentage of interneuronal variability they describe so that the first PC (PC1) is the combination of gene expression values that are expressed the most variably, whereas PC10 is the combination that is expressed the least variably. In our study, lower order PCs best delineate differences in mRNA expression among neurons, whereas the higher order PCs best represent neuronal similarities and, arguably, a cohesive cellular response. PCs are complex ratios of genes, and their construction is based on log-transformed data (Rohif and Bookstein, 1990; Craig et al., 1997). For our purposes we explored PC gene ratios that elicited a unified cellular response among SHAM CA1 neurons to establish a "diagnostic" molecular fingerprint for comparison across treatment groups. By carefully studying how this fingerprint changes in response to treatment, we can perform future experiments to test generated hypotheses. To this end, we explored the higher order PCs as candidates to define a complex ratio that was expressed consistently, i.e., a PC ratio in which the numerator and denominator genes were expressed in each of the SHAM CA1 neurons examined.

Next, univariate analyses were performed on the ratio conveyed by the selected PC. The ratio was constructed mathematically in SAS (Statistical Analysis Systems, 1990), using only those genes with coefficients that dominated the PC structure $(\geq 0.2)$. The univariate procedures calculated the means of this ratio for each treatment group and generated comparisons of their statistical significance $(p<0.05)$ across treatment groups, using the least-squares means option in the general linear models (GLM) procedure extension of ANOVA. Statistical significance for all of the univariate analyses was set at the $\alpha 0.05(p<0.05)$ level (Sokal and Rohif, 1981). The Hartley's $F_{\text {Max }}$ statistic was used to test for equality of variances among treatment groups for the ratio of gene expression (Mason et al., 1989). All statistical computations, with the exception of the Hartley's $F_{\text {Max }}$ statistic, were performed by SAS.

\section{RESULTS}

We examined the effects of chronic exposure to CORT on electrophysiological and molecular markers of neuronal $\mathrm{Ca}$ influx in individual CA1 neurons. As an experimental approach to alter chronically the daily CORT intake, we adrenalectomized rats and offered them low or high CORT doses in their drinking water. Previous studies indicate that in this paradigm rats still exhibit a considerable degree of variation in circulating CORT levels during the day because of differences in activity levels and drinking patterns, similar to what occurs in adrenally intact rats, but not with pellet administration of CORT (Akana et al., 1988; Jacobson et al., 1988). From their fluid intake it is clear that CORT was ingested successfully by both the ADC-LO (0.76 mg/rat per day) and the ADC-HI groups (10.28 mg/rat per day) (Table 1). Further, the average weight gain in the ADC-HI group was significantly lower than the weight gains in the other treatment groups (Table 1), suggesting that the former group ingested high levels of CORT.

The four experimental groups differed with respect to their daily CORT intake (Table 1 ). In addition, because daily variations in circulating CORT levels previously have been observed (Akana et al., 1988; Jacobson et al., 1988), we thought it necessary to examine how mRNA expression and $\mathrm{Ca}$ current properties correlate both with circulating CORT levels several hours before the experiment as well as with the average daily CORT intake shown in Table 1. Interestingly, plasma CORT levels at the start of the experiment observed for the ADX and ADC-LO groups were extremely low for both, although daily CORT exposure is different for these two groups. This is likely attributable to the time of sampling relative to drinking patterns in the context of the 
extremely short plasma half-life of CORT (Jacobson et al., 1988; Sloviter et al., 1989; Shors et al., 1990). Further, plasma CORT levels in sham-operated animals are greater than those in ADX animals treated with high CORT, likely attributable to the acute stress related to their exposure to a novel environment 30-60 min before their deaths. Acutely dissociated CA1 neurons were examined first for effects of steroid treatment on whole-cell $\mathrm{Ca}$ conductance properties, as described elsewhere (Vreugdenhil and Wadman, 1992). Actual Ca current amplitudes correlated with plasma CORT levels shortly before the experiment, rather than with changes in daily average CORT intake (see Whole-Cell Calcium Currents below).

Next, cellular contents were aspirated into the recording pipette. Single-cell antisense RNA amplification and expression profiling were performed to characterize simultaneous expression of candidate mRNAs as a function of long-term CORT treatment in individual CA1 neurons (Eberwine et al., 1992). All data analysis was performed with ImageQuant software. Specific hybridization to each cDNA clone was calculated by subtracting nonspecific hybridization (to control vector sequence) from total hybridization. Within each blot, specific signals for cDNA clones corresponding to voltage-gated $\mathrm{Ca}$ channels and NMDA receptor subunits were expressed relative to the "inhibitory component," i.e., the sum of specific signals for $\alpha$-subunits $(\alpha 1-\alpha 6)$ comprising the $\mathrm{GABA}_{\mathrm{A}}$ receptor in the same blot. Recent in situ hybridization data suggest that neither adrenalectomy nor CORT replacement $(100 \mathrm{mg} / \mathrm{ml}$ in drinking water, i.e., $5 \times$ the CORT concentration administered to the ADC-HI group) led to alterations in levels of $\alpha$-subunit mRNAs comprising the $\mathrm{GABA}_{\mathrm{A}}$ receptor in the CA1 (Orchinik et al., 1994). Levels of AMPA receptor mRNAs were expressed relative to the sum of the specific signals for all AMPA receptor mRNAs. Principal component (PCA) and univariate ratio analyses additionally were performed on expression data from individual samples in each treatment group. These procedures were performed jointly to identify mRNA combinations that reflect cellular activities involved in normal CA1 neuronal behavior and their possible regulation by exposure to CORT.

\section{Voltage-gated calcium channel mRNAs}

Hybridization to cDNAs corresponding to $\alpha 1 \mathrm{~A}, \alpha 1 \mathrm{~B}$, and $\alpha 1 \mathrm{C} / \mathrm{D}$ subunit mRNAs (encoding P/Q-, N-, and L-type voltage-gated $\mathrm{Ca}$ channels, respectively) was detected in every individual CA1 neuron (Fig. 1). In all rat hippocampal CA1 pyramidal neurons characterized to date, $\alpha 1 \mathrm{~B}$ mRNA was far more abundant (74$88 \%$ of all $\alpha 1$ subunit mRNAs) than $\alpha 1 \mathrm{~A}(7-16 \%)$ or $\alpha 1 \mathrm{C} / \mathrm{D}$ (4-19\%) mRNAs (Fig. 2).

Expression levels for the $\alpha 1 \mathrm{~A}$ Ca channel subunit mRNA were not altered after 4 weeks in ADX neurons when compared with SHAM controls (Fig. 2A). However, $\alpha 1 \mathrm{~A}$ mRNA levels were reduced significantly in ADC-LO neurons relative to both groups of controls $(p<0.05)$. Neurons in ADX rats treated with high CORT expressed significantly higher $\alpha 1 \mathrm{~A}$ mRNA levels than ADC-LO neurons $(p<0.001)$ or untreated ADX neurons $(p<$ $0.05)$. In contrast to the $\alpha 1 \mathrm{~A}$ subunit mRNA, steady-state levels of $\alpha 1 \mathrm{~B}$ mRNA were not affected significantly by any of the steroid treatments (Fig. 2B).

Chronic absence of circulating CORT (untreated ADX group) resulted in a significant elevation of neuronal levels of $\alpha 1 \mathrm{C} / \mathrm{D}$ mRNA relative to SHAMs. ADX neurons treated with low CORT expressed significantly lower levels of $\alpha 1 \mathrm{C} / \mathrm{D}$ mRNA than untreated ADX controls $(p<0.05$; Fig. $2 C$ ). Additional occupa-

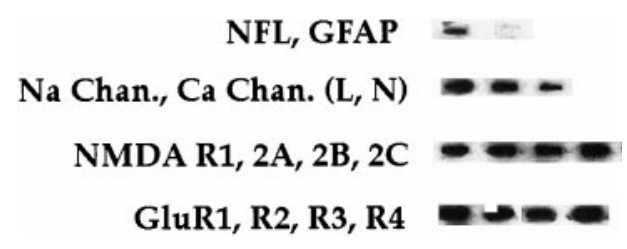

Figure 1. Expression profile of various candidate genes in hippocampal pyramidal cells. One microgram each of cDNA containing plasmid for various genes was linearized with EcoRI or HindIII, heat-denatured, and gravity-applied to a nylon membrane filter, using a slot blotter. The filter was UV-cross-linked with a Stratalinker (Stratagene, La Jolla, CA), followed by prehybridization as described (Craig et al., 1997). Radiolabeled aRNA from an individual neuron was hybridized for $2 \mathrm{~d}$ as described (Craig et al., 1997). The filters were washed with increasing stringencies to a final wash stringency of $0.1 \times \mathrm{SSC}, 0.1 \% \mathrm{SDS}$ at $55^{\circ} \mathrm{C}$ for $30 \mathrm{~min}$. The filters either were placed on a phosphoimager screen for analysis or were apposed to film for $3 \mathrm{~d}$, followed by developing in an automated film developer.

tion of GRs in ADC-HI neurons led them to express $\alpha 1 \mathrm{C} / \mathrm{D}$ mRNA at levels that were significantly higher than those seen in the ADC-LO group $(p<0.05) . \alpha 1 \mathrm{C} / \mathrm{D}$ expression levels in ADC-HI neurons were indistinguishable from those observed in ADX controls, but higher than in SHAMs $(p<0.05)$.

Thus, mRNA expression of $\mathrm{Ca}$ channel subunits is altered by chronic changes in steroid levels. Chronically low average CORT levels result in low expression patterns for $\alpha 1 \mathrm{~A}$ and $\alpha 1 \mathrm{C} / \mathrm{D}$ mRNAs, whereas both in the absence of steroids $(\alpha 1 \mathrm{C} / \mathrm{D})$ and with chronic increase of the average CORT level ( $\alpha 1 \mathrm{~A})$, a relative enhancement of subunit mRNA expression can be observed.

\section{AMPA receptor subunit mRNAs}

Alterations in steady-state mRNA levels of flop AMPA receptor subunits (GluR-1 through GluR-4) were characterized as a function of differential corticosteroid receptor occupation. GluR-1 mRNA was, relatively speaking, the most abundant transcript, whereas GluR-4 mRNA was barely detectable in neurons from sham-operated animals. Thus, GluR-1 through GluR-3 subunit mRNAs were coexpressed in individual CA1 neurons.

In the present study the relative levels of GluR-1 and GluR-3 subunit mRNAs were comparable for all treatment groups (Fig. $3 A$ ) (data not shown). GluR-2 mRNA expression was not altered after 4 weeks of adrenalectomy relative to sham controls. However, ADC-LO neurons expressed $\sim 74 \%$ more GluR-2 mRNA relative to untreated ADX and SHAM neurons $(p<0.001$; Fig. $3 B)$. This increase was reversed in ADC-HI neurons, which expressed $\sim 49 \%$ less GluR-2 mRNA relative to the low CORTtreated group.

Selective occupation of MRs increased the relative abundance of GluR-2 mRNA, such that the ratio of GluR-1 to GluR-2 mRNA levels was $\sim 2: 1$. Lack of occupation of MRs and GRs in untreated ADX neurons, as well as their simultaneous occupation in ADC-HI neurons, decreased the relative abundance of GluR-2 mRNA, resulting in a GluR-1 to GluR-2 mRNA ratio of $\sim 3: 1$.

\section{NMDA receptor subunit mRNAs}

In the present study, individual CA1 neurons coexpressed NMDA receptor mRNAs for the glutamate-responsive NR1, NR2A, 2B, and 2C subunit proteins. In SHAM neurons, the relative order of abundance was NR1 mRNA (35\%), NR2A (27.5\%), NR2B (17.5\%), and NR2C (20\%).

No alterations were detected in levels of NR1 (Fig. 4) or NR2C mRNAs among any of the experimental groups. Similarly, no differences were observed in NR2A and NR2B expression in 


\section{A. P/Q-TYPE}

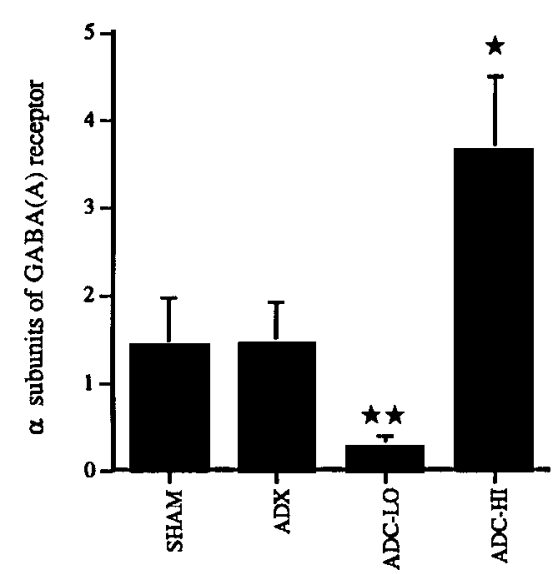

B. N-TYPE

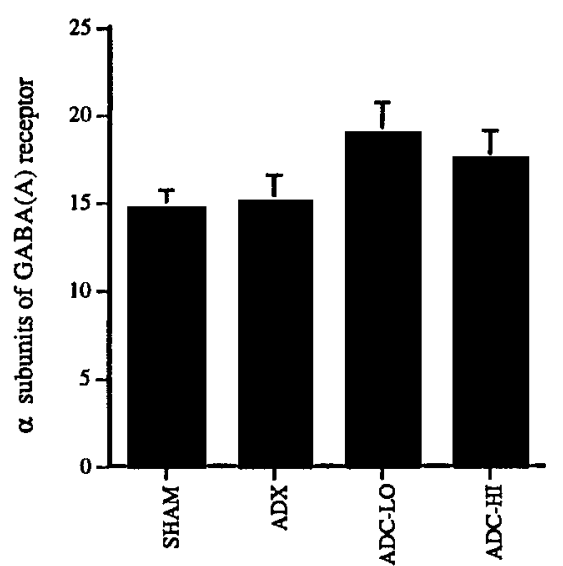

C. L-TYPE

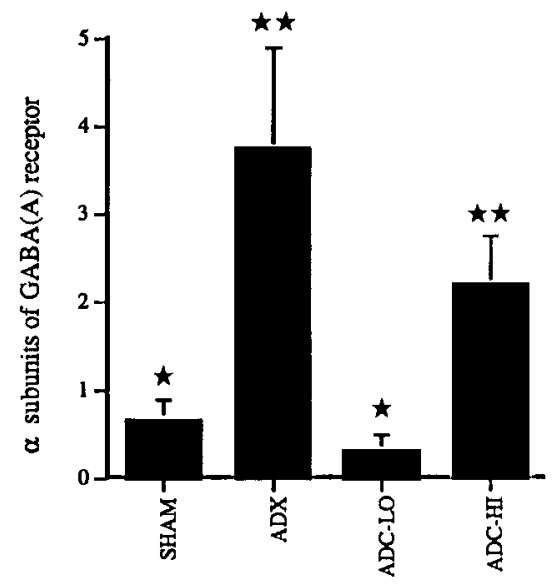

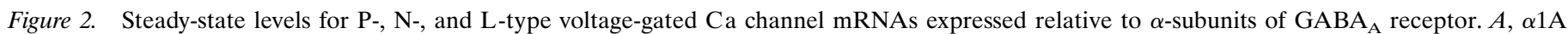
(P-type) mRNA levels are not altered in dispersed CA1 neurons from ADX rats relative to those from SHAM controls. Furthermore, $\alpha 1 \mathrm{~A}$ mRNA levels are not altered in ADC-LO neurons relative to both SHAM and ADX neurons. However, steady-state levels of $\alpha 1 \mathrm{~A}$ mRNA are significantly higher in ADC-HI relative to ADC-LO neurons $(p<0.001)$ and relative to SHAM and ADX neurons $(p<0.05)$. A single star indicates a significant difference from SHAM, ADX, and ADC-LO; double stars indicate a significant difference from SHAM, ADX and ADC-HI. $B, \alpha 1 B$ (N-type) mRNA levels are statistically indistinguishable in both low and high CORT-treated neurons relative to SHAM and ADX neurons. $C, \alpha 1 \mathrm{C} / \mathrm{D}$ mRNA levels are significantly higher in ADX neurons relative to SHAM controls $(p<0.05)$. ADC-LO neurons express significantly lower levels of $\alpha 1 \mathrm{C} / \mathrm{D}$ mRNA relative to ADX neurons $(p<0.05)$. ADC-HI neurons expressed significantly higher levels of $\alpha 1 \mathrm{C} / \mathrm{D}$ mRNA relative to neurons from the ADC-LO treatment group $(p<0.05)$. Expressed levels of $\alpha 1 \mathrm{C} / \mathrm{D}$ mRNA are statistically indistinguishable between CA1 neurons from the ADX and ADC-HI treatment groups. A single star indicates a significant difference from ADX and ADC-HI; double stars indicate a significant difference from SHAM and ADC-LO.

A. GluR-1

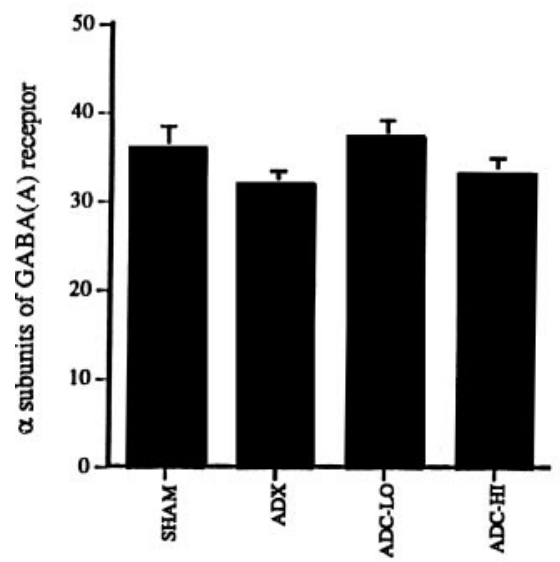

B. GluR-2

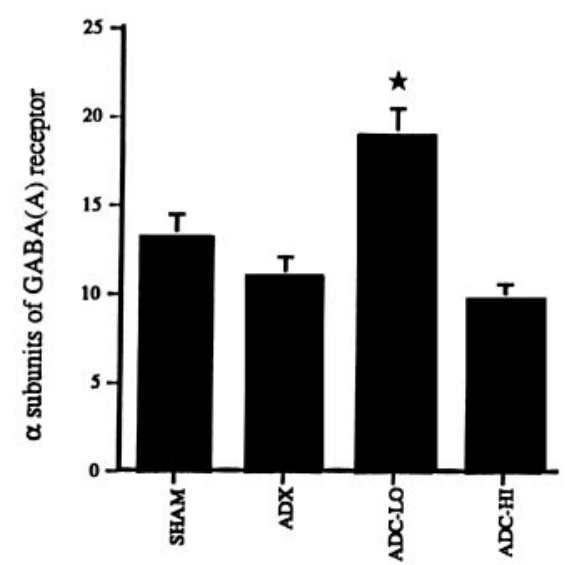

C. GluR1:GluR-2

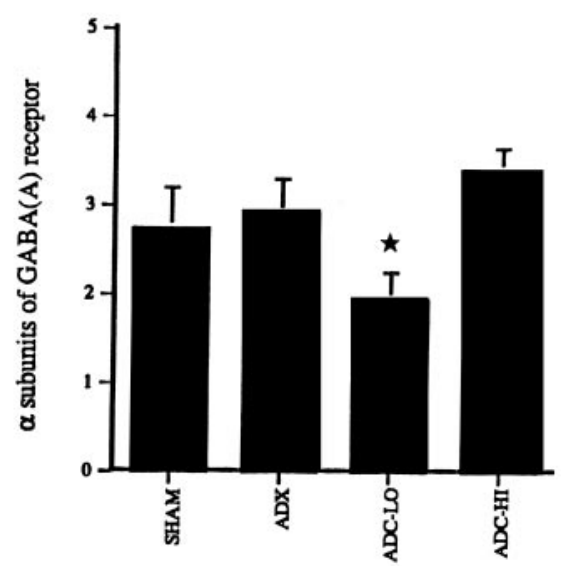

Figure 3. Steady-state levels of GluR-1 and GluR-2 mRNAs: AMPA receptor subunits expressed relative to total AMPA receptor subunit signal (GluR-1 through GluR-3). A, Levels of GluR-1 mRNAs are not altered in low or high CORT-treated neurons relative to SHAM or ADX controls after 4 weeks of treatment. $B$, ADC-LO neurons express significantly higher levels of GluR-2 mRNA relative to both SHAM and ADX controls $(p<0.001)$. ADC-HI neurons show a significant reduction in levels of expression of GluR-2 mRNA relative to ADC-LO neurons $(p<0.001)$ at levels similar to those seen in SHAM and ADX neurons. $C$, The ratio of GluR-1 to GluR-2 mRNA levels is statistically indistinguishable among SHAM, ADX, and ADC-HI CA1 neurons. This ratio is significantly lower in ADC-LO neurons relative to other treatment groups $(p<0.05)$. A star indicates a significant difference from SHAM, ADX, and ADC-HI.

ADX neurons when compared with SHAMs. ADC-LO neurons expressed significantly higher levels of NR2A mRNA than neurons in either the SHAM or ADX group $(p<0.05)$; no further alteration was observed in ADC-HI neurons (Fig. $4 B$ ). On the other hand, NR2B mRNA levels were significantly lower in ADC-LO neurons relative to the SHAM and ADX groups $(p<$ $0.05)$ and to the ADC-HI group ( $p<0.001$; Fig. $4 C)$. The ratios of NR2A to NR2B mRNA levels in ADX and ADC-HI neurons were 1.6:1 and 1.8:1, respectively. However, in low CORT-treated neurons this ratio was $\sim 6: 1$ (Fig. $4 D$ ).

\section{Whole-cell calcium currents}

$\mathrm{Ca}$ currents were evoked in acutely dissociated neurons by the voltage protocol depicted in Figure $5 A$. As described elsewhere, 
A. NR1

Figure 4. Relative levels of mRNAs encoding the NMDA receptor subunits NR1, NR2A, NR2B, and NR2C expressed relative to $\alpha$-subunits of $\mathrm{GABA}_{\mathrm{A}}$ receptor. $A$, NR1 mRNA levels are unaltered in ADC-LO and ADC-HI neurons relative to SHAM and ADX control neurons. $B, \mathrm{NR} 2 \mathrm{~A}$ mRNA levels are unaltered between ADX and SHAM neurons $(p<0.05)$. However, ADC-LO neurons express significantly higher levels of NR2A mRNA relative to ADX neurons $(p<$ $0.05)$. Levels of NR2A mRNA in ADC-HI neurons are not significantly different from those expressed by SHAM, ADX, or ADC-LO neurons. A star indicates a significant difference from SHAM and ADX. $C, \mathrm{NR} 2 \mathrm{~B}$ mRNA levels are unaltered between ADX and SHAM-dispersed CA1 neurons. Levels of NR2B mRNA are significantly lower in ADC-LO relative to SHAM and ADX neurons $(p<$ $0.05)$. NR2B mRNA levels are significantly higher in ADC-HI neurons relative to ADC-LO neurons $(p<$ 0.001). A star indicates a significant difference from SHAM, ADX, and ADC-HI. $D$, The ratio of NR2A to NR2B mRNA levels is statistically indistinguishable among dispersed CA1 neurons from the SHAM, ADX, and ADC-HI treatment groups. This ratio is significantly higher in ADC-LO neurons relative to other treatment groups $(p<0.05)$. A star indicates a significant difference from SHAM, ADX, and ADC-HI.

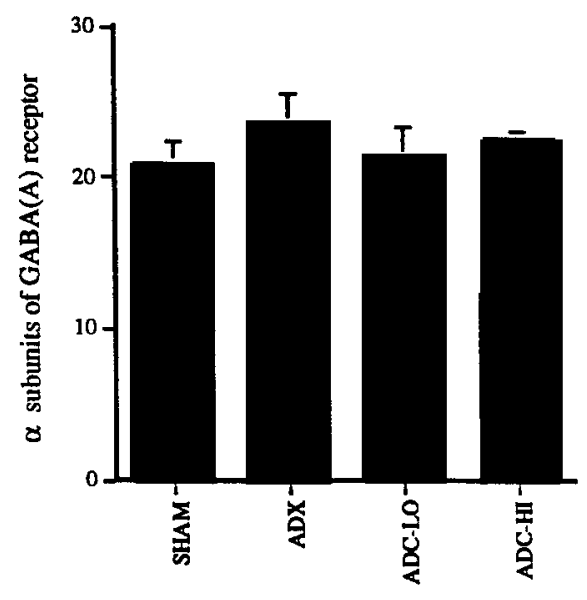

C. NR2B

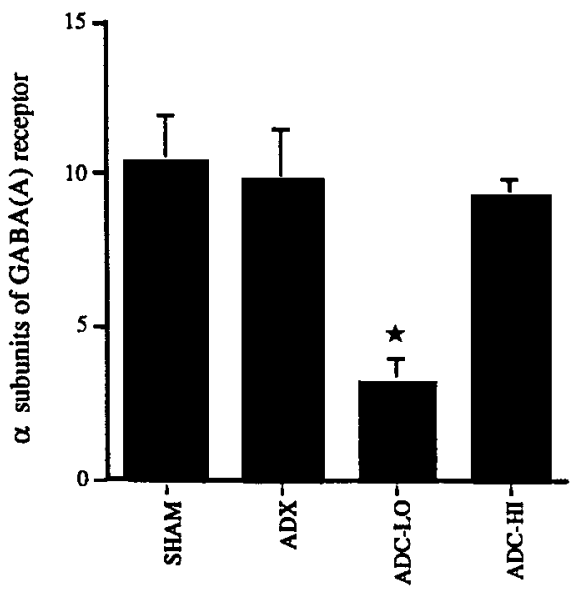

B. NR2A

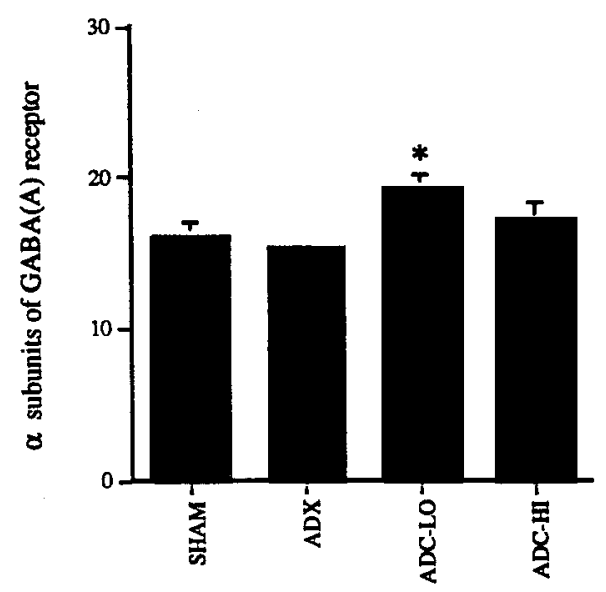

D. NR2A:NR2B these currents mainly consisted of L- and N- type Ca currents (Thompson and Wong, 1991). From each cell the membrane input impedance, capacitance, and the current-voltage relationship for the peak amplitude of the Ca current were determined (Table 1).

Average peak Ca current amplitude for a voltage step to $10 \mathrm{mV}$ was not different in the ADC-LO group $(1.1 \pm 0.1 \mathrm{nA})$ when compared with the untreated ADX group $(1.0 \pm 0.1 \mathrm{nA}$; SHAMoperated controls, $1.3 \pm 0.1 \mathrm{nA}$ ). As shown in Figure $5 B$, we also tested peak $\mathrm{Ca}$ current amplitudes as a function of plasma CORT levels at the start of the experiment. Ca current amplitudes were relatively high when considered in the group of animals with extremely low (0-1 $\mu \mathrm{g}$ CORT/100 ml plasma) or moderately high (>5 $\mu \mathrm{g} / 100 \mathrm{ml}$ plasma) circulating CORT levels, whereas significantly lower $\mathrm{Ca}$ current amplitudes were observed in neurons from animals with intermediate $(2-5 \mu \mathrm{g} / 100 \mathrm{ml}$ plasma) CORT levels (Fig. 5B).

The data suggest that, in the present experimental paradigm, peak $\mathrm{Ca}$ current amplitudes may correlate with circulating
CORT levels several hours before the start of the experiment rather than with average daily CORT intake.

\section{Principal components and univariate ratio analyses}

SHAM mRNA expression data for the 10 genes described above were consolidated into eigenvector (coefficient)-based variables called principal components or PCs (see Materials and Methods). $\mathrm{PC} 1$ has the highest variance $(32.8 \%$; data not shown) relative to the remaining PCs, because it expresses the largest percentage of variability in mRNA expression in SHAM neurons; each successive PC seeks to decrease this variability. We specifically selected PC10 for further analysis because it suggested a biologically plausible scenario in addition to accounting for the smallest percentage of variability, i.e., $<0.01 \%$. The coefficients with the highest values $(\geq 0.2)$ were identified; the gene combination (GluR2.NMDAR-2A)/(GluR3.NMDAR-1) dominated PC10, making it an excellent candidate for a "diagnostic" molecular fingerprint. This gene subset is used in all further discussions of PC10, with genes represented by positive coefficients (GluR-2 and 
A
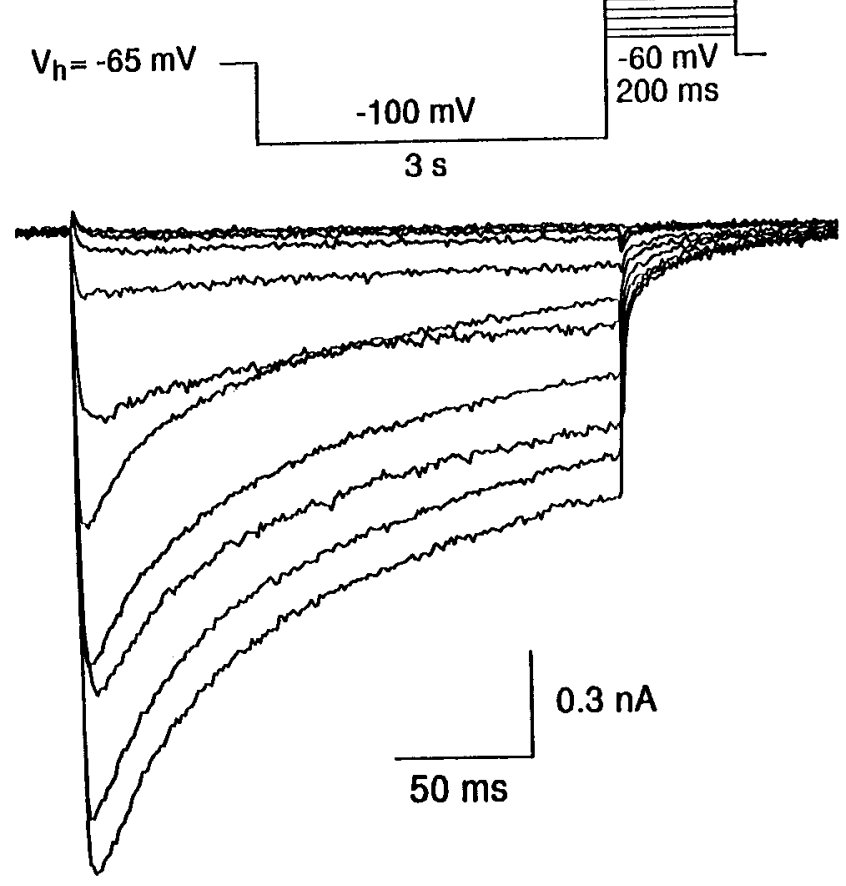

$+30 \mathrm{mV}$

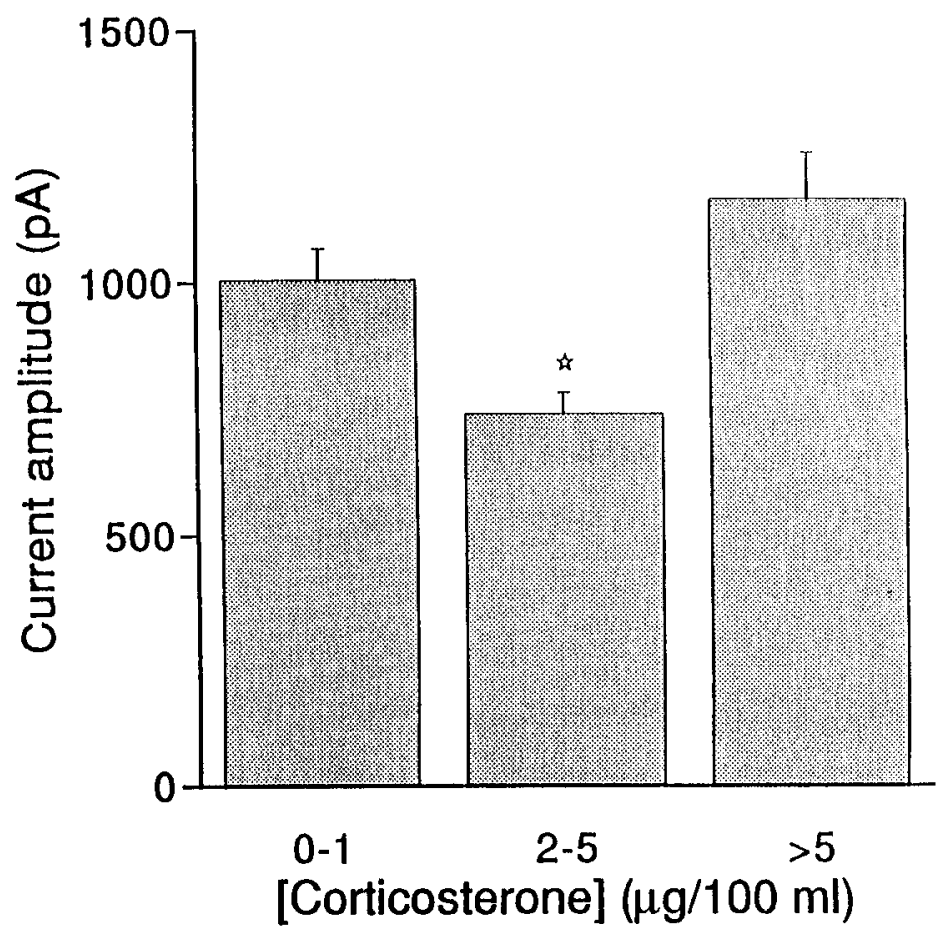

Figure 5. Ca current amplitudes vary with plasma CORT level at the start of the experiment. $A$, Ca currents were evoked in acutely dissociated CA1 hippocampal cells by brief $(200 \mathrm{msec})$ depolarizing steps to voltages between -60 and $+30 \mathrm{mV}$, preceded by a hyperpolarizing $(-100 \mathrm{mV})$ prepulse of $3 \mathrm{sec}$ duration from a holding potential of $-65 \mathrm{mV}$ (see inset for voltage protocol). $B$, The amplitude of the Ca current induced by a voltage step to 10 $\mathrm{mV}$ was depicted as a function of the plasma [CORT] at the start of the experiment. In the (near) absence of CORT $(0-1 \mu \mathrm{g} / 100 \mathrm{ml}$ plasma; $n=37)$ or when CORT levels were moderately high $(>5 \mu \mathrm{g} ; n=17)$, the average Ca current amplitudes were higher than when CORT levels were at an intermediate level $(2-5 \mu \mathrm{g} ; n=7)$. A star indicates a significant difference from $0-1$ and $>5$.

NMDAR-2A) in the numerator and those with negative coefficients (GluR-3 and NMDAR-1) in the denominator.

In Figure 6, the PCs plot and bar graph represent the treatment group relationships determined by this initial analysis. CA1 neurons from each treatment group are plotted against the numerator and denominator genes that characterize PC10 (Fig. 6b), revealing cellular distributions within each treatment group. SHAM CA1 neurons are clustered closely around their mean, indicating that this ratio was expressed consistently from one neuron to the next. ADC-HI CA1 neurons also demonstrated a linear relationship, whereas ADX and ADC-LO neurons were clustered in nonlinear groups, implying erratic expression of these genes in the latter. The variance test determined that the distributions of the neuron groups were statistically distinct from one another $(p<0.05)$, with the exception of the comparison between ADC-HI and SHAM neurons.

Chronic ADX treatment did not alter the mean PC10 ratio (Fig. 6b) relative to SHAMs. However, ADC-LO neurons expressed a mean PC10 value distinct from the means of the other three groups $(p<0.05)$, whereas ADC-HI neurons were not distinguishable from SHAM or ADX neurons (Fig. 6b). There are also significant slope differences among SHAM, ADC-LO, and ADC-HI groups (Fig. 6b), i.e., CORT treatment has a disruptive effect on the relationship between the numerator and denominator genes expressed in SHAM neurons.

The neuronal interrelationships illustrated in Figure $6 a$, to- gether with the least-squares mean ratio expression values (Fig. $6 b$ ) and Hartley's $F_{\text {Max }}$ test for variance equality (data not shown), distinguished the neuron groups. From Figure $6 b$ it is clear that an inverted U-shaped dose relationship exists between the extent of MR and GR occupation and the PC10 ratio of gene expression in CA1 neurons.

\section{DISCUSSION}

In this study we observed that chronic activation of MRs and GRs by CORT regulates expression levels of mRNAs encoding voltage- and ligand-gated ion channels in individual CA1 neurons. This suggests that CORT may exert receptor-dependent actions on fundamental properties of these neurons, including ion influx and synaptic transmission, as well as susceptibility to neurodegenerative processes.

We first examined the $\alpha 1$ subunits of voltage-gated Ca channels, the sequences for which have been cloned recently (Dunlap et al., 1989). Of these, the $\alpha 1 \mathrm{~A}$ subunits constitute channels with properties of the $\mathrm{P} / \mathrm{Q}$-type $\mathrm{Ca}$ channels, $\alpha 1 \mathrm{~B}$ subunits of $\mathrm{N}$-type channels, and $\alpha 1 \mathrm{C} / \mathrm{D}$ subunits of L-type Ca channels (Varadi et al., 1995). In our study chronically altered CORT intake affects relative mRNA expression levels of subunits of the $\mathrm{P} / \mathrm{Q}-$ and L-type channels, but not of the N-type Ca channel. Specifically, in the absence of steroid, increased expression was observed for the L-type channel subunit mRNA and, to a lesser extent, for the $\mathrm{P} / \mathrm{Q}$-type channel subunit mRNA. However, P/Q- and L-type Ca 
b.

a.

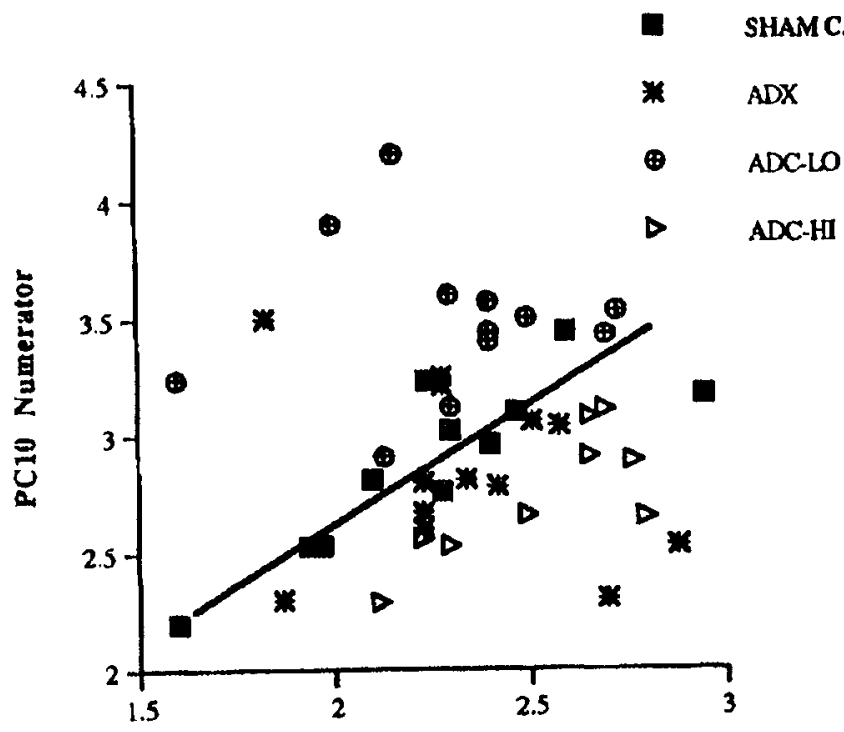

PC10 Denominator

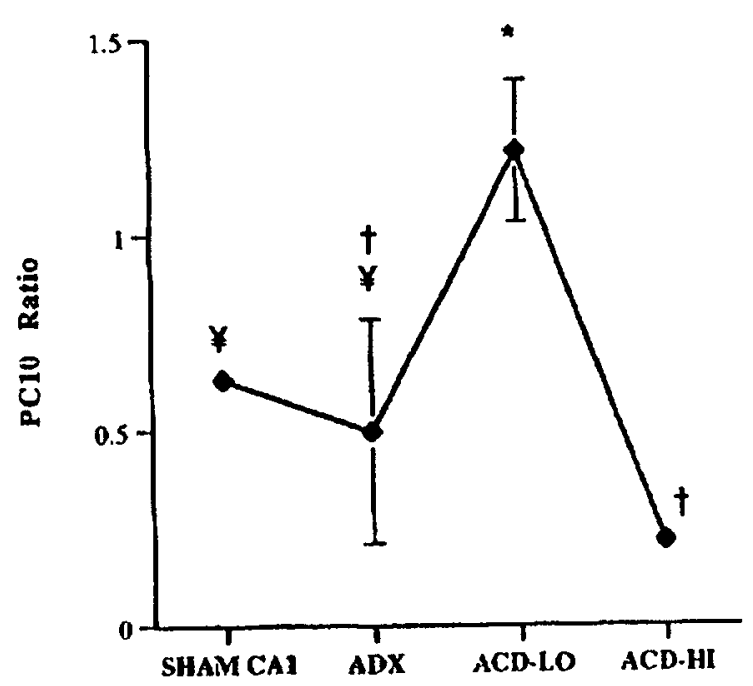

Treatment

Figure 6. Plots of the numerator and denominator genes comprising the PC10 ratio derived from the expression data (additive coefficients are based on log-transformed cpms) for AMPA and NMDA receptor subunit mRNAs. $a$, Each point represents a single neuron from SHAM, ADX, ADC-LO, and ADC-HI animals. Numbers on the ordinate and abscissa for each plot reflect the scale resulting from construction of separate linear combinations of PC10 coefficients representing the numerator (GluR-2 + NMDAR-2A) and denominator (GluR-3 + NMDAR-1), respectively. The tight clustering of SHAM CA1 data points along its line indicates a unified cellular response to the ratio. Dispersal from the central line represents an alteration, i.e., a "disruption" in the unified cellular response to the ratio. *Significant slope differences relative to SHAM neurons. $b$, Shown are mean expression level values and SE of the PC10 ratio across treatment groups; means with the same symbol are not significantly different $(p>0.05)$.

channel subunit mRNA levels were low in ADC-LO neurons (animals that chronically received low CORT in their drinking water). Finally, chronic exposure to high CORT led to high levels of expression for the $\mathrm{P} / \mathrm{Q}$-type and L-type channel subunit mRNAs in ADC-HI neurons relative to ADC-LO neurons.

P-type $\mathrm{Ca}$ channels are associated predominantly with stimulus-coupled exocytosis in the mammalian brain (Dunlap et al., 1989) and are present at both excitatory and inhibitory synapses (Luebke et al., 1993; Takahashi and Momiyama, 1993; Castillo et al., 1994) in the hippocampus (Llinás et al., 1992; Mintz et al., 1992). Therefore, if the mRNA changes observed in our study (see Fig. 2) lead to alterations in protein expression, chronically negligible or high CORT may increase the relative contribution of P/Q-type Ca current and consequently may modulate exocytosis mediated by these channels. Conversely, our data imply that chronic low CORT may lead to an opposite shift in P/Q-type Ca current-mediated function. Expression levels of mRNAs encoding $\omega$-CgTx-sensitive $\mathrm{N}$-type $\mathrm{Ca}$ channels are not altered by either dose of CORT after 4 weeks. This fraction of the $\mathrm{Ca}$ current is associated with cooperative regulation of stimulation-coupled secretion events in hippocampal neurons, along with P/Q-type Ca channels (Dunlap et al., 1989; Wheeler et al., 1994). Therefore, CORT may not regulate N-type currentmediated synaptic transmission by actions on either MRs or GRs in CA1 neurons. Further, chronic absence of CORT or high CORT may increase the relative numbers of L-type Ca channels, whereas low CORT results in mRNA levels that correlate with decreased expression. L-type channels regulate levels of cytosolic calcium (Dunlap et al., 1989; Hell et al., 1993) and can activate other channels directly, regulate gene expression (Morgan and Curran, 1986; Murphy et al., 1991), and activate a number of
Ca-dependent protein kinases and phosphatases (Kennedy, 1989). Differential corticosteroid receptor activation therefore may modulate $\mathrm{Ca}$-dependent signal transduction mechanisms mediated by L-type channels in CA1 neurons.

Interestingly, although the potential for $\mathrm{Ca}$ influx in animals subjected to low daily CORT intake may be downregulated, measured $\mathrm{Ca}$ currents in ADC-LO were seen to be comparable to those from SHAM controls. Accordingly, whole-cell Ca current amplitudes correlated with plasma CORT levels at the start of the experiment (see Fig. 5) - as opposed to average daily CORT intake - displaying a U-shaped dose dependency, as has been observed previously for the steroid regulation of $\mathrm{Ca}$ currents and other electrical responses of hippocampal cells in slices (Joëls and de Kloet, 1994; Karst et al., 1994). This may be because acutely dissociated neurons lack part of the dendritic tree where steroid-sensitive $\mathrm{Ca}$ channels have been shown to be located (Karst et al., 1993, 1994); MR-mediated events also have been shown to be less apparent in this neuronal preparation (Werkman et al., 1997). Further, Ca currents recorded in the whole-cell configuration show fewer differences in their dynamic range (Zhu and Ikeda, 1994) so that downregulation of Ca channel number may have been less apparent in terms of whole-cell $\mathrm{Ca}$ conductances. Other ionic conductances, either not regulated by CORT or not examined in this study, also may contribute to measured whole-cell Ca currents in CA1 neurons. Finally, observed differences between electrophysiological and molecular data may be attributable to the actions of CORT at different regulatory sites, e.g., regulation of protein synthesis to modulate $\mathrm{Ca}$ currents (Karst and Joëls, 1991; Kerr et al., 1992) in addition to regulation of mRNA expression levels over the long term. The precise 
relationship among measured CORT levels, Ca currents, and mRNA expression needs to be clarified by future experiments.

Ionotropic glutamate receptors responsive to AMPA mediate most of the rapid synaptic excitatory transmission in the CNS (Sommer and Seeburg, 1992). Assembly of the GluR-2 subunit has been shown to be responsible for the very low $\mathrm{Ca}$ permeability and linear current-voltage $(I-V)$ relationship exhibited by native AMPA receptors (Hollmann et al., 1991; Verdoorn et al., 1991; Jonas and Sakmann, 1992). In our study the contribution of GluR-2 relative to GluR-1 mRNA was increased significantly in ADC-LO animals, as compared with the ADX and ADC-HI groups (see Fig. 3). This suggests that predominant activation of MRs may restrict AMPA receptor-gated current, whereas lack of activation of either MRs or GRs or their simultaneous activation may enhance this current in CA1 neurons. Therefore, the extent of occupation of MRs and GRs may modulate resting Ca conductance and fast synaptic transmission mediated by AMPA receptors. GluR-1, R-2, and R-3 subunit mRNAs are expressed in alternatively spliced forms in the hippocampus (Sommer et al., 1990), whereas GluR-2 mRNA undergoes RNA editing (Hollmann et al., 1991). We currently are investigating the potential roles of RNA editing and alternative splicing of GluR-2 mRNA in the context of our observations.

The NMDA glutamate-responsive receptor is distributed widely in the CNS. This ligand-gated ion channel mediates cationic synaptic transmission and plays a pivotal role in developmental synaptic plasticity and excitotoxic cell death (Mayer and Westbrook, 1987; Tymianski et al., 1994). In previous experiments NR1, NR2A, and NR2B mRNAs were shown to be expressed at moderate to high levels in pyramidal neurons in the hippocampus (Monyer et al., 1992, 1994). These investigators detected NR2C transcripts only in a subset of hippocampal neurons, presumably interneurons, at much lower levels. In our study, however, individual CA1 neurons were seen to coexpress NR1, 2A, 2B, and 2C mRNAs (see Fig. 1). Our ability to detect NR2C mRNA in every CA1 neuron that was examined may be attributable to the increased sensitivity of detection afforded by singlecell aRNA analysis relative to in situ hybridization studies previously performed on whole-brain sections (Eberwine et al., 1992). This study represents the first observation that NR1, NR2A, 2B, and $2 \mathrm{C}$ mRNAs are coexpressed in individual CA1 neurons from the postnatal rat hippocampus.

CA1 neurons with predominant activation of MRs (ADC-LO) expressed a significantly higher ratio $(\sim 6: 1)$ of NR2A to NR2B mRNA relative to neurons in which corticosteroid receptors were either simultaneously activated (ADC-HI) or simultaneously inactivated (ADX) (1.6:1 and 1.8:1, respectively) (see Fig. 4). In previous experiments, recombined heteromeric NR1-NR2A channels from rat brain exhibited faster $(4 \times)$ offset decay times but similar reversal potentials relative to recombinant NR1NR2B channels (Monyer et al., 1994; Burnashev et al., 1995); theoretically, this should result in relatively restricted $\mathrm{Ca}$ influx via the former class of channels. Indeed, in Xenopus oocytes, recombinant mouse NR1-NR2B receptors gated Ca currents that were approximately twice as large as those carried by NR1NR2A receptors (Kutsuwada et al., 1992; Meguro et al., 1992; Scheetz and Constantine-Paton, 1994); further, NR1-NR2B receptors were approximately twice as sensitive to L-glutamate as NR1-NR2A receptors were. Finally, evoked NMDA receptormediated postsynaptic currents in slices from neonatal rats (which express the NR1 and NR2B subunits) were of longer duration relative to those from adult rats that expressed the NR2A subunit in addition to NR1 and NR2B (Kato et al., 1991; Hestrin, 1992).

Therefore, our data suggest that NMDA receptor subunit composition may be modulated by CORT. Chronic MR activation may result in significantly restricted $\mathrm{Ca}$ influx in $\mathrm{CA} 1$ neurons relative to those from $\mathrm{ADX}$ and $\mathrm{ADC}-\mathrm{HI}$ animals. This regulation is likely to have two components: an altered sensitivity of the heteromeric NMDA receptor to L-glutamate and altered $\mathrm{Ca}$ influx as a function of channel kinetics, both of which result in smaller currents being gated by NMDA receptors in ADC-LO neurons. Some investigators, however, have found no differences between NR1-NR2A and NR1-NR2B heteromeric channels in human embryonic kidney (HEK 293) cells, both at the level of single-channel conductances and whole-cell Ca currents (Stern et al., 1992; Anegawa et al., 1995). This may reflect differences in the properties of their expression system relative to neurons. Recent studies also have shown that NMDA receptors may exist as complex heteromeric receptors containing both NR2A and NR2B subunits, a condition that complicates interpretation of our data (Sheng et al., 1994).

The above data show that chronically low daily CORT intake results in low expression levels of mRNAs encoding $\mathrm{P}$ and L-type $\mathrm{Ca}$ channel subunits, high mRNA expression of the GluR-2 versus GluR-1 subunit, and a significantly higher ratio of NR2A to NR2B mRNA when compared with animals with no circulating CORT or who are exposed to a high daily CORT intake. Our data therefore suggest that expression of these neuronal mRNAs is regulated reciprocally by $\mathrm{MR}$ activation relative to no activation or simultaneous activation of MRs and GRs in CA1 neurons. If these changes are, indeed, translated into protein expression, MR activation may result in a tighter regulation of $\mathrm{Ca}$ influx, whereas chronic activation of both MRs and GRs may lead to enhanced $\mathrm{Ca}$ influx (Table 2). It is possible that alterations in mRNA expression observed in ADC-LO neurons arise in part because of chronic lack of GR activation rather than solely as a functional consequence of chronic MR activation. In the present study we cannot distinguish between these two effects. Lack of receptor occupation in ADX samples leads to levels of mRNA expression similar to the ADC-HI group.

The combined results of PC and univariate statistical analyses are consistent with the above observations (see Fig. 6). Normal physiology of SHAM CA1 neurons is maintained by complex interactions between expression levels of numerous neuronal proteins and mRNAs that encode them. We feel that univariate methods of analysis are insufficient to identify and characterize these interactions, both in normal and altered physiological states. However, multivariate approaches, e.g., PCA, have been used for such purposes before (Bennett et al., 1997; Craig et al., 1997). It is used in the present study as an exploratory tool to identify possible interrelationships among expression of the 10 neuronal genes already described. For this purpose, mRNA expression data first were consolidated mathematically into coefficient-based variables known as PCs (see Materials and Methods). PC1 has a high variance relative to the remaining PCs; each successive PC consecutively explains the remainder of the variability. Higher order PCs are less variable, e.g., in the present analysis PC10 represents the least variability $(0.0 \%)$ and therefore (arguably) a cohesive cellular response in SHAM neurons. For this reason, we chose to analyze further the variables that comprise PC10.

The ratio of expression levels of GluR-2 and NMDAR-2A relative to GluR-3 and NMDAR-1 was found to be the dominant variable in PC10. This suggests that individual SHAM neurons 


\begin{tabular}{|c|c|c|c|}
\hline & $\begin{array}{l}\text { ADX-No receptor } \\
\text { occupation }\end{array}$ & $\begin{array}{l}\text { LO-CORT-MR } \\
\text { activation }\end{array}$ & $\begin{array}{l}\text { HI-CORT-MR + } \\
\text { GR activation }\end{array}$ \\
\hline \multicolumn{4}{|l|}{ Voltage-gated $\mathrm{Ca}$ channel mRNAs ( $\alpha 1$ subunits) } \\
\hline P/Q-type & $\uparrow$ & $\downarrow$ & $\uparrow$ \\
\hline N-type & $\leftrightarrow$ & $\leftrightarrow$ & $\leftrightarrow$ \\
\hline L-type & $\uparrow$ & $\downarrow$ & $\uparrow$ \\
\hline \multicolumn{4}{|l|}{ AMPA receptor subunit mRNAs } \\
\hline GluR-1 & $\leftrightarrow$ & $\leftrightarrow$ & $\leftrightarrow$ \\
\hline GluR-2 & $\downarrow$ & $\uparrow$ & $\downarrow$ \\
\hline GluR-3 & $\leftrightarrow$ & $\leftrightarrow$ & $\leftrightarrow$ \\
\hline GluR1:GluR2 & $\downarrow$ & $\uparrow$ & $\downarrow$ \\
\hline \multicolumn{4}{|l|}{ NMDA receptor subunit mRNAs } \\
\hline NR1 & $\leftrightarrow$ & $\leftrightarrow$ & \\
\hline NR2A & $\leftrightarrow$ & $\uparrow$ & $\leftrightarrow$ \\
\hline NR2B & $\uparrow$ & $\downarrow$ & $\uparrow$ \\
\hline $\mathrm{NR} 2 \mathrm{C}$ & $\leftrightarrow$ & $\leftrightarrow$ & $\leftrightarrow$ \\
\hline NR2A:NR2B & $\downarrow$ & $\uparrow$ & $\downarrow$ \\
\hline Potential biological consequences on $\mathrm{Ca}$ conductance in $\mathrm{Ca} 1$ neurons & $\uparrow$ Ca-influx & $\downarrow$ Ca-influx & $\uparrow$ Ca-influx \\
\hline
\end{tabular}

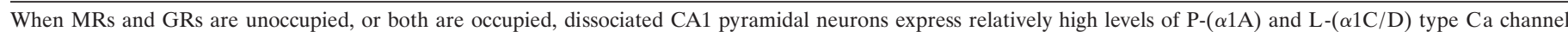

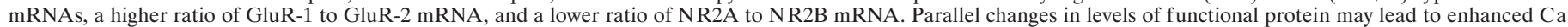

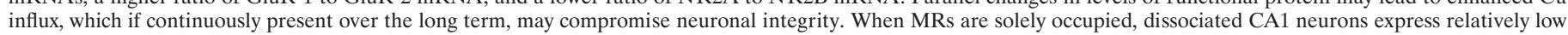

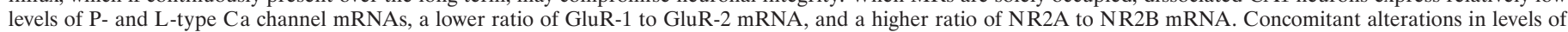
functional protein may act to limit $\mathrm{Ca}$ influx, contributing to the previously observed neuroprotective effect of MR occupation.

may seek to maintain this ratio, perhaps as a necessary requirement for normal biological function. Thus, an increase in GluR-2 mRNA may lead to a parallel increase in GluR-3 mRNA expression to maintain AMPA receptor expression and function; similarly, a particular ratio of NMDA receptor subunits may serve to maintain NMDA receptor-mediated $\mathrm{Ca}$ influx under normal conditions. Also, mutually regulated interactions between the AMPA and NMDA receptor systems that are modulated by CORT cannot be ruled out on the basis of these data.

Chronic ADX treatment, i.e., chronic lack of occupation of MRs and GRs, substantially decreases the ability of CA1 neurons to maintain this ratio; individual ratios are scattered widely around the mean (see Fig. $6 a, b$ ). This scatter is also evident to a lesser extent in ADC-LO neurons, but not in ADC-HI neurons. Further, sole activation of MRs or activation of MRs plus GRs modulates coordinate regulation of these four genes in CA1 neurons differently relative to the SHAM state and from each other (Fig. 6). Both lack of occupation of MRs and GRs and their concomitant activation have similar effects, whereas sole MR activation results in a markedly different ratio, leading to an inverted U-shaped dose-response relationship between the actions of CORT and this ratio in CA1 neurons. This suggests that AMPA and NMDA receptor subunit mRNAs may be regulated by the extent of MR and GR occupation. The exact mechanism, as well as the consequences of MR and GR activation on functions and properties of AMPA and NMDA receptors, needs to be demonstrated directly by future experiments.

The above results mimic at the molecular level what has been observed previously for regulation of neurotransmitter responses and ionic conductances by glucocorticoids (Joëls and de Kloet, 1994); predominant MR activation and MR plus GR activation usually lead to opposite effects. Further, adrenalectomy without steroid replacement induces effects that are remarkably similar to those seen with MR plus GR activation. Thus, steroid regulation of neuronal membrane and neurotransmitter responses usually appears as a U-shaped dose-response curve. Electrophysiological experiments in tissue from mutant mice lacking a functional GR indicate that interactions between MR and GR proteins may be important for the $U$ shape of the curve (Hesen et al., 1996). Homozygous mutants that only express MRs did not show the characteristic depression of Ca current amplitude seen in wildtype controls in the presence of low to moderate levels of circulating CORT.

In summary, MR activation relative to simultaneous lack or presence of activation of MRs and GRs reciprocally regulates coordinate expression of mRNAs that may play a critical role in $\mathrm{Ca}$ permeability and synaptic transmission in CA1 neurons. In this regard, predominant activation of MRS may play a neuroprotective role (Landfield et al., 1981; Gould et al., 1990; Joëls and de Kloet, 1994) relative to conditions in which neither MRs nor GRs are activated or in which both are activated simultaneously in individual CA1 neurons (Elliott and Sapolsky, 1993; Elliot et al., 1993; Stein-Behrens et al., 1994). These molecular events occurring in individual CA1 neurons are in agreement with previous observations that prolonged aberrations in circulating CORT levels are harmful to neuronal integrity in the hippocampus.

\section{REFERENCES}

Akana SF, Jacobson L, Cascio CS, Shinsako J, Dallman MF (1988) Constant corticosterone replacement normalizes basal adrenocorticotropin (ACTH) but permits sustained ACTH hypersecretion after stress in adrenalectomized rats. Endocrinology 122:1337-1342.

Anegawa NJ, Lynch DR, Verdoorn TA, Pritchett DB (1995) Transfection of $N$-methyl-D-aspartate receptors in a non-neuronal cell line leads to cell death. J Neurochem 64:2004-2012.

Armanini MP, Hutchins C, Stein BA, Sapolsky RM (1990) Glucocorticoid endangerment of hippocampal neurons is NMDA receptordependent. Brain Res 532:7-12.

Arriza JL, Weinberger C, Cerelli G, Glaser TM, Handelin BL, Housman DE, Evans RM (1987) Cloning of the human mineralocorticoid receptor complementary DNA: structural and functional kinship with the glucocorticoid receptor. Science 237:268-275. 
Bennett GD, Lau F, Calvin JA, Finnell RH (1997) Phenytoin-induced teratogenesis: a molecular basis for the observed developmental delay during neurulation. Epilepsia 38:415-423.

Bohus B, de Kloet ER, Veldhuis HD (1982) Current topics in neuroendocrinology 1 (Ganten D, Pfaff D, eds), pp 107-149. Berlin: Springer.

Burnashev N, Zhou Z, Neher E, Sakmann B (1995) Fractional calcium currents through recombinant GluR channels of the NMDA, AMPA, and kainate receptor subtypes. J Physiol (Lond) 485:403-418.

Castillo P, Weisskopf MG, Nicoll RA (1994) The role of $\mathrm{Ca}^{2+}$ channels in hippocampal mossy fiber synaptic transmission and long-term potentiation. Neuron 12:261-269.

Chao HM, Choo PH, McEwen BS (1989) Glucocorticoid and mineralocorticoid receptor mRNA expression in rat brain. Neuroendocrinology 50:365-371.

Choi DW (1988) Calcium-mediated neurotoxicity: relationship to specific channel types and role in ischemic damage [review]. Trends Neurosci 11:465-469.

Craig JC, Eberwine JH, Calvin JA, Wlordarczyk B, Bennett GD, Finnell RH (1997) Developmental expression of morphoregulatory genes in the mouse embryo: an analytical approach using a novel technology. Biochem Mol Med 60:81-91.

Dunlap K, Luebke JI, Turner TJ (1989) Exocytotic $\mathrm{Ca}^{2+}$ channels in mammalian central neurons. Trends Neurosci 18:89-98.

Eberwine J, Yeh H, Miyashiro K, Cao Y, Nair S, Finnell R, Zettel M, Coleman P (1992) Analysis of gene expression in single live neurons. Proc Natl Acad Sci USA 89:3010-3014.

Elliott E, Sapolsky R (1993) Corticosterone impairs hippocampal neuronal calcium regulation: possible mediating mechanisms. Brain Res 602:84-90.

Elliott E, Mattson M, Vanderklish P, Lynch G, Chang I, Sapolsky R (1993) Corticosterone exacerbates kainate-induced alterations in hippocampal tau immunoreactivity and spectrin proteolysis in vivo. J Neurochem 61:57-67.

Funder JW (1987) Adrenal steroids: new answers, new questions. Science 237:236-237.

Gould E, Woolley CS, McEwen BS (1990) Short-term glucocorticoid manipulations affect neuronal morphology and survival in the adult rat dentate gyrus. Neuroscience 37:367-375.

Hell JW, Westenbroek RE, Warner C, Ahlijanian MK, Prystay W, Gilbert MM, Snutch TP, Catterall WA (1993) Identification and differential subcellular localization of the neuronal class C and class D L-type calcium channel $\alpha 1$ subunits. J Cell Biol 123:949-962.

Herman JP, Patel PD, Akil H, Watson SJ (1989) Localization and regulation of glucocorticoid and mineralocorticoid receptor messenger RNAs in the hippocampal formation of the rat. Mol Endocrinol 3:1886-1894.

Hesen W, Karst H, Meijer O, Cole TJ, Schmid W, de Kloet ER, Schutz G, Joëls M (1996) Hippocampal cell responses in mice with a targeted glucocorticoid receptor gene disruption. J Neurosci 16:6766-6774.

Hestrin S (1992) Developmental regulation of NMDA receptormediated synaptic currents at a central synapse. Nature 357:686-689.

Hollenberg SM, Weinberger C, Ong ES, Cerelli G, Oro A, Lebo R, Thompson EB, Rosenfeld MG, Evans RM (1985) Primary structure and expression of a functional human glucocorticoid receptor cDNA. Nature 318:635-641.

Hollmann M, Hartley M, Heinemann S (1991) $\mathrm{Ca}^{2+}$ permeability of KA-AMPA-gated glutamate receptor channels depends on subunit composition. Science 252:851-853.

Jacobson L, Akana SF, Cascio CS, Shinsako J, Dallman MF (1988) Circadian variations in plasma corticosterone permit normal termination of adrenocorticotropin responses to stress. Endocrinology 122:1343-1348.

Joëls M, de Kloet ER (1989) Effects of glucocorticoids and norepinephrine on excitability in the hippocampus. Science 245:1502-1505.

Joëls M, de Kloet ER (1994) Mineralocorticoid and glucocorticoid receptors in the brain. Implications for ion permeability and transmitter systems. Prog Neurobiol 43:1-36.

Joëls M, de Kloet ER (1996) Corticosteroid hormones in neuroprotection and brain damage. Curr Opin Endocrinol Diabetes 3:184-192.

Johnson RA, Wichern DW (1992) Applied multivariate statistical analysis (Conmy SR, ed), pp 356-395. Englewood Cliffs, NJ: Prentice Hall.

Jonas P, Sakmann B (1992) Glutamate receptor channels in isolated patches from CA1 and CA3 pyramidal cells of rat hippocampal slices. J Physiol (Lond) 455:143-171.
Karst H, Joëls M (1991) The induction of corticosteroid actions on membrane properties of hippocampal CA1 neurons requires protein synthesis. Neurosci Lett 130:27-32.

Karst H, Joëls M, Wadman WJ (1993) Low-threshold calcium current in dendrites of adult rat hippocampus. Neurosci Lett 164:154-158.

Karst H, Wadman WJ, Joëls M (1994) Corticosteroid receptordependent modulation of calcium currents in rat hippocampal CA1 neurons. Brain Res 649:234-242.

Kato N, Artola A, Singer W (1991) Developmental changes in the susceptibility to long-term potentiation of neurones in rat visual cortex slices. Dev Brain Res 60:43-50.

Kay AR, Wong RKS (1986) Calcium current activation kinetics in isolated pyramidal neurones of the CA1 region of the mature guinea-pig hippocampus. J Physiol (Lond) 392:603-616.

Kennedy MB (1989) Regulation of neuronal function by calcium. Trends Neurosci 12:417-420.

Kerr DS, Campbell LW, Hao S-Y, Landfield PW (1989) Corticosteroid modulation of hippocampal potentials: increased effect with aging. Science 245:1505-1507.

Kerr DS, Campbell LW, Thibault O, Landfield PW (1992) Hippocampal glucocorticoid receptor activation enhances voltage-dependent $\mathrm{Ca}$ conductances: relevance to brain aging. Proc Natl Acad Sci USA 89:8527-8531.

Kutsuwada T, Kashiwabuchi N, Mori H, Sakimura K, Kushiya E, Araki K, Meguro H, Masaki H, Kumanishi T, Arakawa M, Mishina M (1992) Molecular diversity of the NMDA receptor channel. Nature 358:36-41.

Landfield P, Baskin R, Pitler T (1981) Brain aging correlates: retardation by hormonal pharmacological treatments. Science 214:581-584.

Llinás R, Sugimori M, Hillman DE, Cherksey B (1992) Distribution and functional significance of the P-type, voltage-dependent $\mathrm{Ca}^{2+}$ channels in the mammalian central nervous system. Trends Neurosci 15:351-355.

Luebke JI, Dunlap K, Turner TJ (1993) Multiple calcium channel types control glutaminergic synaptic transmission in the hippocampus. Neuron 11:895-902.

Mason RL, Gunst RF, Hess JL (1989) Statistical design and analysis of experiments, pp 265, 650. New York: Wiley.

Mayer ML, Westbrook GL (1987) The physiology of excitatory amino acids in the central nervous system. Prog Neurobiol 28:197-276.

McEwen BS, de Kloet ER, Rostene W (1986) Adrenal steroid receptors and actions in the nervous system [review]. Physiol Rev 66:1121-1188.

Meguro H, Mori H, Araki K, Kushiya E, Kutsuwada T, Yamazaki M, Kumanishi T, Arakawa M, Sakimura K, Mishina M (1992) Functional characterization of a heteromeric NMDA receptor channel expressed from cloned cDNAs. Nature 357:70-74.

Mintz IM, Adams ME, Bean BP (1992) P-type calcium channels in rat central and peripheral neurons. Neuron 9:85-95.

Monyer H, Sprengel R, Schoepfer R, Herb A, Higuchi M, Lomeli H, Burnashev N, Sakmann B, Seeburg PH (1992) Heteromeric NMDA receptors: molecular and functional distinction of subtypes. Science 256:1217-1221.

Monyer H, Burnashev N, Laurie DJ, Sakmann B, Seeburg PH (1994) Developmental and regional expression in the rat brain and functional properties of four NMDA receptors. Neuron 12:529-540.

Morgan JI, Curran T (1986) Role of ion flux in control of c-fos expression. Nature 322:552-556.

Murphy TH, Worley PF, Baraban JM (1991) L-type voltage-sensitive calcium channels mediate synaptic activation of immediate early genes. Neuron 7:625-635.

Orchinik M, Weiland NG, McEwen BS (1994) Adrenalectomy selectively regulates $\mathrm{GABA}_{\mathrm{A}}$ receptor subunit expression in the hippocampus. Mol Cell Neurosci 5:451-458.

Rao CR (1973) Linear statistical inference and its applications. New York: Wiley.

Reul JMHM, de Kloet ER (1985) Two receptor systems for corticosterone in rat brain: microdistribution and differential occupation. Endocrinology 117:2505-2511.

Rohif JF, Bookstein FL (1990) Traditional morphometrics. In: Proceedings of the Michigan morphometrics workshop, University of Michigan Museum of Zoology (Rohif JF, Bookstein FL, eds), pp 77-122. Ann Arbor, MI: University of Michigan.

Rousseau GG (1984) Control of gene expression by glucocorticoid hormones. Biochem J 224:1-12.

Sapolsky RM, Pulsinelli WA (1985) Glucocorticoids potentiate ischemic injury to neurons: therapeutic implications. Science 229:1397-1400. 
Sapolsky RM, Krey LC, McEwen BS (1985) Prolonged glucocorticoid exposure reduces hippocampal neuron number: implications for aging. J Neurosci 5:1222-1227.

Sapolsky RM, Packan D, Vale W (1988) Glucocorticoid toxicity in the hippocampus: in vitro demonstration. Brain Res 453:367-372.

Scheetz AJ, Constantine-Paton M (1994) Modulation of NMDA receptor function: implications for vertebrate neural development. FASEB J $8: 745-752$.

Sheng M, Cummings J, Roldan L, Jan YN, Jan LY (1994) Changing subunit composition of heteromeric NMDA receptors during development of rat cortex. Nature 368:144-147.

Shors TJ, Levine S, Thompson RF (1990) Effect of adrenalectomy and demedullation on the stress-induced impairment of long-term potentiation. Neuroendocrinology 51:70-75.

Sloviter R, Valiquette G, Abrams G, Ronk E, Sollas A, Paul L, Neurbort S (1989) Selective loss of hippocampal granule cells in the mature rat brain after adrenalectomy. Science 243:535-538.

Sokal RR, Rohif FJ (1981) Biometry. San Francisco: Freeman.

Sommer B, Seeburg PH (1992) Glutamate receptor channels: novel properties and new clones. Trends Pharmacol Sci 13:291-296.

Sommer B, Keinanen K, Verdoorn TA, Wisden W, Burnashev N, Herb A, Kohler M, Takagi T, Sakmann B, Seeburg PH (1990) Flip and flop: a cell-specific functional switch in glutamate-operated channels of the CNS. Science 249:1580-1585.

Statistical Analysis Systems Institute (1990) SAS/STAT user's guide, release 6.03. Philadelphia: SAS Institute.

Stein-Behrens B, Mattson MP, Chang I, Yeh M, Sapolsky R (1994) Stress exacerbates neuron loss and cytoskeletal pathology in the hippocampus. J Neurosci 14:5373-5380.

Stern P, Behe P, Schoepfer R, Colquhoun D (1992) Single-channel con- ductances of NMDA receptors expressed from cloned cDNAs: comparison with native receptors. Proc R Soc Lond [Biol] 250:271-277.

Takahashi T, Momiyama A (1993) Different types of calcium channels mediate central synaptic transmission. Nature 366:156-158.

Thompson SM, Wong RKS (1991) Development of calcium current subtypes in isolated rat hippocampal pyramidal cells. J Physiol (Lond) 439:671-689.

Tymianski M, Charlton MP, Carlen PL, Tator CH (1994) Properties of neuroprotective cell-permeant $\mathrm{Ca}^{2+}$ chelators: effects on $\left[\mathrm{Ca}^{2+}\right]_{\mathrm{i}}$ and glutamate neurotoxicity in vitro. J Neurophysiol 72:1973-1992.

Varadi G, Mori Y, Mikala G, Schwartz AM (1995) Molecular determinants of $\mathrm{Ca}^{2+}$ channel function and drug action. Trends Pharmacol 16:43-49.

Verdoorn TA, Burnashev N, Monyer H, Seeburg PH, Sakmann B (1991) Structural determinants of ion flow through recombinant glutamate receptor channels. Science 252:1715-1718.

Vreugdenhil M, Wadman WJ (1992) Enhancement of calcium current in rat hippocampal CA1 neurons induced by kindling epileptogenesis. Neuroscience 49:373-381.

Werkman TR, van der Linden S, Joëls M (1997) Corticosteroid effects on sodium and calcium currents in acutely dissociated rat CA1 hippocampal neurons. Neuroscience 78:663-672.

Wheeler DB, Randall A, Tsien RW (1994) Roles of N-type and Q-type $\mathrm{Ca}^{2+}$ channels in supporting synaptic transmission. Science 264:107-111.

Woolley C, Gould E, McEwen BS (1990) Exposure to excess glucocorticoids alters dendritic morphology of adult hippocampal pyramidal neurons. Brain Res 531:225-231.

Zhu Y, Ikeda SR (1994) Modulation of $\mathrm{Ca}^{2+}$ channel currents by protein kinase $\mathrm{C}$ in adult rat sympathetic neurons. J Neurophysiol 72:1549-1560. 